\title{
A comparison of pitfall traps and hand-picking techniques for studying macroathropods abundance in vegetable plots and the influence of abiotic factors on their abundance in Jos, Nigeria
}

\author{
Ishaya M. ${ }^{1}$, Mwansat G. S. ${ }^{2}$, Ombugadu A. ${ }^{{ }^{\star}}$, Njila H. L. ${ }^{4}$, Mafuyai M. J. ${ }^{1}$ and Lapang M. P. ${ }^{2}$ \\ 1Department of Pest Management Technology, Federal College of Forestry, Jos, Nigeria. \\ ${ }^{2}$ Department of Zoology, Faculty of Natural Sciences, University of Jos, Jos, Nigeria. \\ ${ }^{3}$ Department of Zoology, Faculty of Science, Federal University Lafia, Nasarawa State, Nigeria. \\ ${ }^{4}$ Department of Science Laboratory Technology, Faculty of Natural Sciences, University of Jos, Jos, Nigeria. \\ ${ }^{*}$ Corresponding author. Email: akwash24@gmail.com. Tel: +2348034867540.
}

Copyright @ 2018 Ishaya et al. This article remains permanently open access under the terms of the Creative Commons Attribution License 4.0, which permits unrestricted use, distribution, and reproduction in any medium, provided the original work is properly cited.

Received 3rd May, 2018; Accepted 28th June, 2018

\begin{abstract}
Soil macroarthropods are important components that sustain the health and quality of agro-ecosystems for improved agricultural productions though are influenced by abiotic components of the environment. Macroarthropod collections vary across traps due to the fact that some traps can stand for a long time while others such as handpicking cannot. However, traps may be used as a rapid assessment tool to generate checklists for macroarthropod species present in an area within a very short time. To this end, a study on the comparison of pitfall traps and hand-picking techniques for studying macroathropods abundance in vegetable plots and the influence of abiotic factors (temperature and $\mathrm{pH}$ ) on their abundance in Jos, Nigeria was carried out from August to October, 2014. Pitfall traps and hand-picking techniques were used to collect macroarthropods from six different vegetable plots in three selected villages in Jos North Local Government Area of Plateau State, Nigeria. Soil temperature was recorded in the field while soil samples were obtained from a $7.5 \mathrm{~cm}$ depth for measurement of soil pH in the laboratory. A total of 3,346 macroarthropods were collected and pitfall traps had 2,780 (83.08\%) while handpicking technique recorded $566(16.92 \%)$. There was a significant difference $(P=0.0076)$ in the mean abundance of macroarthropods between sampling techniques. Macroarthropods abundance and species richness in relation to vegetable plots varied significantly $(P<0.0001)$. There was a positive association between $\mathrm{pH}$ and macroarthropod abundance $(r=0.13)$ while temperature did not influence the abundance $(r$ $=-0.08$ ). Although, pitfall trap is a passive collector of macroarthropods, it is still a more efficient and preferred sampling techniques for ground crawling arthropods. Farmers should ensure that their soil pH is well maintained at alkaline level so as to influence macroathropods abundance in vegetable plots and ensure robust productivity.
\end{abstract}

Keywords: Abundance, hand-picking, macroarthropods, physico-chemical parameters, pitfall trap, vegetable plots.

\section{INTRODUCTION}

Arthropods are the insects of major interest in agriculture as they can either be good or harmful to crops or animals. About $85 \%$ of soil fauna comprise arthropods! Burrowing arthropods like termites and ants increase soil aeration, soil porosity and generally improve the structure of the soil. If all insects die, humans would run out of food in 4 years (Thuo, 2016). This is because a huge proportion of our food is pollinated by arthropods - one out of every three bites of food we eat! Indirectly, arthropods have a greater role in the food chain where insects are the main pollinators of flowering plants. Insects like the honey bee, butterfly, some flies and beetles pollinate flowers as they 
fly about searching for nectar and pollen for feed (Thuo, 2016). However, soil fauna remains one of the least known biological frontier, particularly in terms of soil zoology and taxonomy. It represents one of the most complex and yet rewarding areas of current biological exploration (Darlong and Alfred, 1991; Henri et al., 2002). Soil supports a diverse assemblage of macroarthropods distinct from microarthropods which include Chilopoda, and Diplopoda larvae and sometimes adults of many Orders of insect and Class Arachnida (Manasseh, 2005).

Crop type may influence the distribution of those members of the soil fauna that are specifically associated with particular food plants. Monoculture may eliminate those arthropods species which are associated with other plants. Crop rotation decreases species diversity to a greater extent (Edwards and Lofty, 1969) than imagined. There is a general decrease in the diversity and abundance of soil fauna when soil is ploughed and planted with crops. Crops that require high agricultural inputs like fertilizers, herbicides and pesticides also influence the diversity and abundance of arthropods. For example, cabbage, tomato, tobacco etc. are prone to arthropod pests attack and therefore, application of synthetic pesticides to control these pests is deleterious to the natural enemies of these pests thereby resulting in population explosion of these pests (Croft, 1990). On the other hand, application of insecticides may increase the number of insects resurgence (Mafuyai, 2014).

Topping and Sunderland (1992) revealed that catches by pitfall trap may be influenced by their timing and placements. Animals that enter pitfall traps are unable to escape being a form of passive collection, as opposed to active collection such as handpicking where the collector catches each animal with hand (Ellis, 2013). The abiotic factors that may affect the abundance of macroarthropods include geographical and ecological conditions (Davidson and Grieve, 2006) which influences the heating up of the soil surface and the movement of heat through the soil profile (DeVries, 1963); soil texture and structure (Johansson et al., 1995); moisture or soil humidity (Anthony, 1977; Roth, 1985); temperature and soil pH.

Increase in temperature from global warming will cause major changes in the abundance and diversity of arthropods, their geographical distribution, their population dynamics, insect biotypes, activity/abundance of natural enemies and species extinction (Sharma, 2013). Such changes include: rapid population growth of arthropods, extension of their geographical range, extinction of some species especially in the tropics, increased over-wintering, evolvement of new biotypes and increase in the activity and abundance on predatory species (Sharma, 2013). Soil temperature influences the types and rate of chemical reactions and the biological processes that occur in the soil (Hillel, 1980). High pH value means that the medium is alkaline and in case of soil it means that the soil is rich in plant nutrients whereas, low $\mathrm{pH}$ signifies acidity and limited quantity of plant nutrients. High $\mathrm{pH}$ is associated with increased abundance of arthropods (Swift and Woomer, 1993). Borer et al. (2012) observed that macroarthropods abundance and diversity is influenced throughout the trophic chain via bottom-up effects based on plant species richness (Scherber et al., 2010) and plant diversity (Hooper et al., 2005). Apart from control through food source, arthropod populations are influenced by top-down control via the abundance of their natural enemies such as the presence of high predator populations tend to reduce their population (Walker and Jones, 2003).

Insect pests cause significant yield losses to vegetable and other crop farmers grow in sub Saharan Africa. Furthermore, there is paucity of information on macroarthropods abundance and their association with physico-chemical parameters in Jos North Local Government Area of Plateau State, Nigeria. Thus, this study compared macroarthropods abundance in relation to type of vegetable plots, trapping methods (pitfall traps and hand-picking techniques) and the influence of abiotic factors on their abundance in Jos, Nigeria.

\section{MATERIALS AND METHODS}

\section{Study area}

The study was carried out between August and October 2014 in Jos, the capital of Plateau State in North Central Nigeria. Jos is located at the extreme north of Plateau State. Jos North, Local Government Area (LGA) is located on $9^{\circ} 55^{\prime} \mathrm{N}$ and $8^{\circ} 54^{\prime} \mathrm{E}$ (Figure 1) at an altitude of approximately $1200 \mathrm{~m}$ above sea level. The natural vegetation of Jos Plateau is the Northern Guinea Savannah grassland. The edaphic feature is laterite and sandy soils that differ across the Plateau (University of Jos Meteorological Station, 2012).

\section{Sampling sites}

The study area was divided into three sampling sites. These sites were selected based on their involvement in mass vegetable production. They are Lamingo, Amazah (Mazah) and Kunga villages. A total of six major vegetable crops grown in Jos North LGA were selected. Each sampling site was subdivided into four plots. The following crops were selected in various sites: Lamingo village, tomato, potato, maize and carrot; Mazah village, cabbage, potato, carrot and maize, while in Kunga village, potato, maize, carrot and lettuce were selected.

\section{Sampling materials and techniques}

A $10 \times 10$ metre quadrat was used in the six vegetable (tomato, potato, maize, carrot, cabbage and lettuce) plots. Five pitfall traps made from bottles measuring $7 \mathrm{~cm}$ in height were filled up with formalin so as to immobilize 


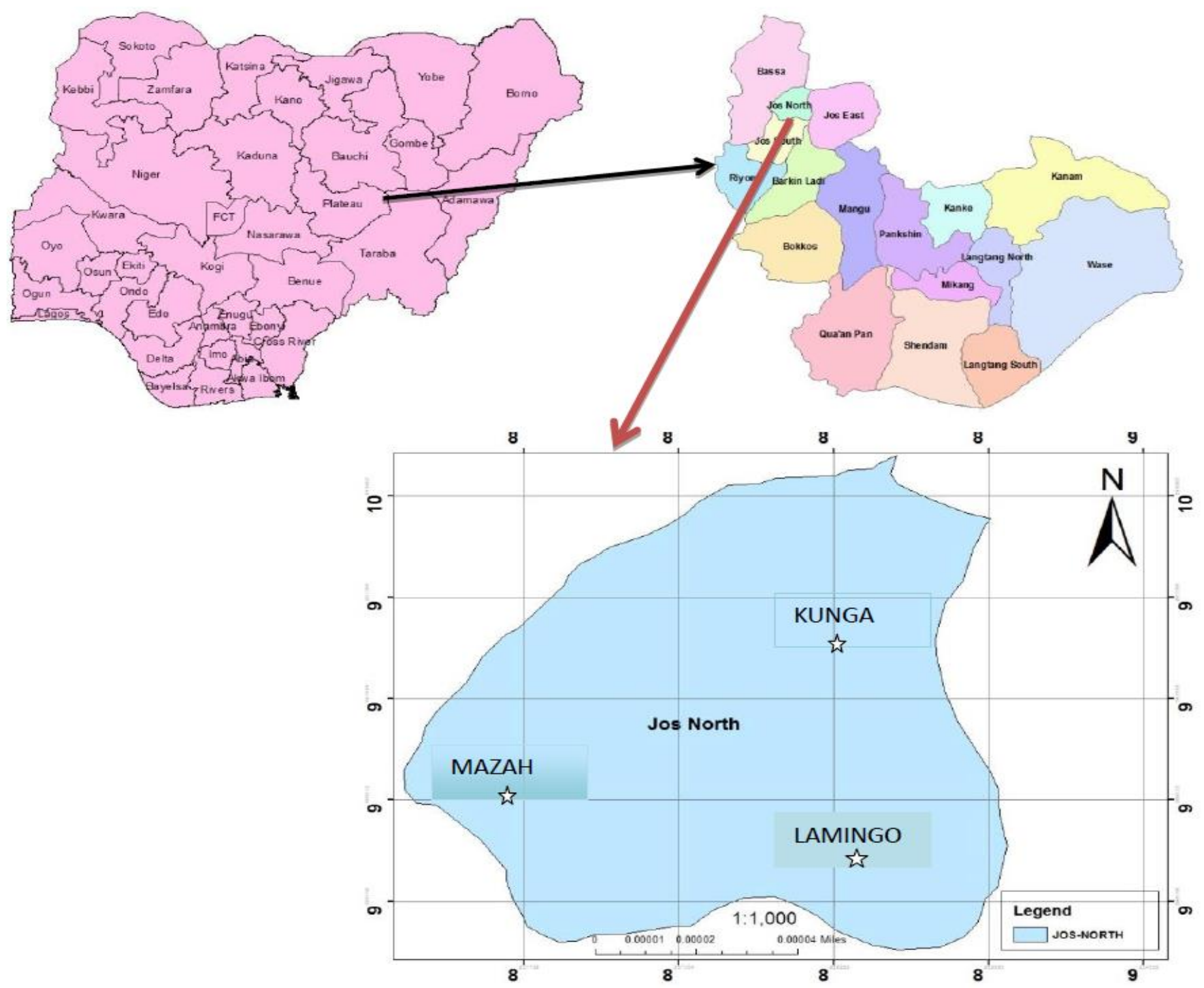

Figure 1. Map of Nigeria showing Plateau State and Plateau State showing Jos North LGA in relation to the three selected study sites.

trapped insect and thereafter a funnel placed at the top were set in the corners and centre of each quadrat. Samples were collected weekly for a standing period of 24 hours (Bater, 1996) at each site. This sampling procedure measures epigeic activity of soil-dwelling animals (Zimmer et al., 2000; Sfenthourakis et al., 2005; Santos et al., 2007). While pitfall traps were set and collection in progress, hand picking technique as adopted by Ellis (2013) and Tuf (2015) was used to collect available macroarthropods that were seen in the morning hours within the experimental plots for five hours. The collected macroarthropods from hand-picking technique were placed in separate collection jars containing cotton wool soaked in chloroform to immobilize active macroarthropods that were further preserved in formalin (Imam et al., 2010).
Macroarthropods collected by both pitfall traps and hand-picking technique were transferred into well labeled collection bottles and taken to the insectary for further sorting and counting.

Soil temperature was measured using hand held thermometer. Also, soil samples were also collected from each sampling sites at the depth of 0 to $7.5 \mathrm{~cm}$. These soil samples were placed in a polythene bags and made airtight to prevent desiccation and spilling of the soil. The soil samples were taken to the Chemistry Laboratory of the Federal College of Forestry Jos where the $\mathrm{pH}$ was determined. During the determination, $10 \mathrm{~g}$ of each soil sample was weighed and placed in a $500 \mathrm{ml}$ flask and 25 $\mathrm{ml}$ of distilled water was added. It was then stirred gently for 1 minute and allowed to stand for 30 minutes. The solution was then decanted into a beaker and the $\mathrm{pH}$ was 
measured using a digital $\mathrm{pH}$ meter.

\section{Identification of Macroarthropods}

At the completion of the collection work, all the preserved macroarthropods were first emptied into a petri dish from the various sample containers, before being identified and counted to ascertain species richness across vegetable plots. Insect identification was carried out in Department of Zoology Insectary, University of Jos with the use of a dissecting microscope and identification keys and illustrations provided by Borror and White (1970), Skaife et al. (1979), Castner (2000) and Shattuck (2000).

\section{Statistical analysis}

The data obtained was analyzed using $\mathrm{R}$ Console Software version 2.9.2. Welch two sample t-test was used to compare the mean abundance between pitfall trap and hand picking techniques. Pearson's Chi-square test was used to compare proportions of macroarthropods abundance and species richness between types of vegetable plots. Pearson's product-moment correlation was used to determine the association between the number of arthropods collected, temperature and soil $\mathrm{pH}$. $P$-values $<0.05$ were considered statistically significant.

\section{RESULTS}

A total of 3346 individual soil arthropods were collected from both sampling techniques. Pitfall traps accounted for 2,780 individuals representing $83.08 \%$ while $566(16.92 \%)$ were collected with hand-picking technique. Therefore, the mean abundance of macroarthropods in relation to the two sampling techniques showed a significant difference $(\mathrm{t}=$ 2.8428, $\mathrm{df}=32.706, \mathrm{P}=0.007647$ ) as shown in Figure 2 .

One hundred and twenty-one macroarthopod species in vegetable plots were identified (Table 1). Tomato plot had the highest number of macroathropods while lettuce plot had the least. Thus, there was a significant difference $\left(\chi^{2}\right.$ $=413, \mathrm{df}=5, \mathrm{P}<0.00001)$ in the abundance of macroarthropods in relation to vegetable plots (Table 2). Furthermore, the species richness in relation to vegetable plots showed a significant difference $\left(\chi^{2}=23.052, \mathrm{df}=5\right.$, $P=0.00033)$. The maize plot had the highest species richness and least in lettuce plot (Table 2).

\section{Effects of physico-chemical parameters on macroarthropods abundance in relation to vegetable plots}

There was a positive correlation $(\mathrm{t}=3.6467, \mathrm{df}=803, \mathrm{P}=$ $0.0002828, r=0.13$ ) between $\mathrm{pH}$ and macroarthropod

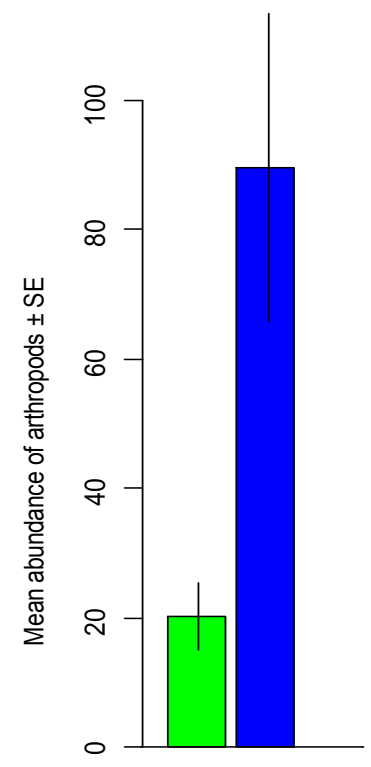

Hand picking Pitfall trap

Figure 2. The mean abundance of macroarthropods in relation to the two collection techniques in 3 selected sites in Jos North, Plateau State.

abundance (Figure 3). The $\mathrm{pH}$ range of the plots was between 7.87 to 8.95 , while temperature range was between 25.7 to $28.0^{\circ} \mathrm{C}$ (Table 3 ). There was negative correlation $(\mathrm{t}=-2.1517$, $\mathrm{df}=803, \mathrm{P}=0.03172, \mathrm{r}=-0.08)$ between temperature and macroarthropods abundance (Figure 4).

\section{DISCUSSION}

The high abundance and species richness recorded in this study clearly shows that the vegetable plots in the three selected sites are homes to a lot of macroarthropods in Jos North LGA of Plateau State, Nigeri. This agrees with the study of Ombugadu et al. (2017) who recorded very high abundance of some macroathropods in farmlands across a protected reserve. Also, Mwansat et al. (2012) reported a high abundance of soil macroarthropods from five selected sites in relation to mass cultivation of four staple food crops: cabbage, maize, potatoes and carrots in Jos South LGA of Plateau State, Nigeria. The high abundance of macroarthropods recorded also implies that these vegetables are exposed to macroarthropod pest's attack. The abundance and species richness of soil macroarthropods observed in this study may be attributed to the availability of resources, principally food. This agrees with the findings of Seastedt and Crossley (2004) who reported that in the presence of abundant resources, arthropods population can grow geometrically or exponentially and when the resources become depleted, the population growth rate slows down and reproductive output by adults become reduced. 
Table 1. Species checklist of macroarthropods of some vegetable plots in Jos North LGA, Plateau State.

\begin{tabular}{|c|c|c|c|c|c|c|}
\hline \multirow{2}{*}{ Species } & \multicolumn{6}{|c|}{ Vegetables } \\
\hline & Cabbage & Carrot & Lettuce & Maize & Potato & Tomato \\
\hline Ataenius alternatus & & $\sqrt{ }$ & & & $\sqrt{ }$ & \\
\hline Alydus calcaratus & & & & $\sqrt{ }$ & $\sqrt{ }$ & $\sqrt{ }$ \\
\hline Achurum carinatum & & $\sqrt{ }$ & & $\sqrt{ }$ & & \\
\hline Anomala distinguenda & $\sqrt{ }$ & & & & & \\
\hline Anthonomus grandis & & & & $\sqrt{ }$ & $\sqrt{ }$ & \\
\hline Archimantis latistyla & & $\sqrt{ }$ & $\sqrt{ }$ & & & \\
\hline Anthocoris nemoralis & & & & & $\sqrt{ }$ & \\
\hline Aulacorthum solani & & & & & $\sqrt{ }$ & \\
\hline Agelenopsis sp. & $\sqrt{ }$ & $\sqrt{ }$ & $\sqrt{ }$ & $\sqrt{ }$ & $\sqrt{ }$ & $\sqrt{ }$ \\
\hline Agelenopsis sp. & $\sqrt{ }$ & $\sqrt{ }$ & & $\sqrt{ }$ & $\sqrt{ }$ & $\sqrt{ }$ \\
\hline Allonemobius sp. & & & & $\sqrt{ }$ & & $\sqrt{ }$ \\
\hline Altica sp. & & & & & $\sqrt{ }$ & \\
\hline Alydus & $\sqrt{ }$ & & & & & \\
\hline Amblyomma sp. & & & & $\sqrt{ }$ & & \\
\hline Anthelephila sp. & $\sqrt{ }$ & & $\sqrt{ }$ & & $\sqrt{ }$ & $\sqrt{ }$ \\
\hline Anomala tibialis & $\sqrt{ }$ & & & & & \\
\hline Balduza bufo & & & & $\sqrt{ }$ & & \\
\hline Blattella germanica & & $\sqrt{ }$ & & & $\sqrt{ }$ & \\
\hline Blattella lituricolis & & & $\sqrt{ }$ & $\sqrt{ }$ & & \\
\hline Bombylius major & & & & & $\sqrt{ }$ & \\
\hline Bombylius sp. & & & & $\sqrt{ }$ & & \\
\hline Bactrododema sp. & & & & & & $\sqrt{ }$ \\
\hline Cydnus aterrimus & $\sqrt{ }$ & & $\sqrt{ }$ & $\sqrt{ }$ & $\sqrt{ }$ & \\
\hline Camponotus consobrinus & $\sqrt{ }$ & $\sqrt{ }$ & & $\sqrt{ }$ & $\sqrt{ }$ & \\
\hline Calopteron discrepans & $\sqrt{ }$ & & & & & \\
\hline Castianeira longipalpis & & & & & $\sqrt{ }$ & \\
\hline Creophilus maxillosus & & $\sqrt{ }$ & & $\sqrt{ }$ & & \\
\hline Carpophilus obsoletus & & $\sqrt{ }$ & $\sqrt{ }$ & $\sqrt{ }$ & & $\sqrt{ }$ \\
\hline Coccinella septempunctata & & $\sqrt{ }$ & $\sqrt{ }$ & $\sqrt{ }$ & $\sqrt{ }$ & $\sqrt{ }$ \\
\hline Calopteron sp. & $\sqrt{ }$ & & & & $\sqrt{ }$ & \\
\hline Camponotus sp. & $\sqrt{ }$ & $\sqrt{ }$ & $\sqrt{ }$ & $\sqrt{ }$ & $\sqrt{ }$ & \\
\hline Chorthippus sp. & & & & $\sqrt{ }$ & $\sqrt{ }$ & \\
\hline Cicindela sp. & & & & & $\sqrt{ }$ & \\
\hline Cantharis tuberculata & & & & $\sqrt{ }$ & & \\
\hline Deloyala guttata & & $\sqrt{ }$ & & & & \\
\hline Dasymutilla quadriguttata & & $\sqrt{ }$ & & $\sqrt{ }$ & & \\
\hline Delphacodes sp. & $\sqrt{ }$ & & & & & \\
\hline Dineutus sp. & & $\sqrt{ }$ & & & $\sqrt{ }$ & \\
\hline Drosophila sp. & $\sqrt{ }$ & $\sqrt{ }$ & $\sqrt{ }$ & $\sqrt{ }$ & $\sqrt{ }$ & $\sqrt{ }$ \\
\hline Dusoria sp. & & & & & $\sqrt{ }$ & \\
\hline Diabrotica undecimpunctata & $\sqrt{ }$ & & & & & \\
\hline Empoasca dolichi & & & & & & $\sqrt{ }$ \\
\hline Euleia fratria & & & & $\sqrt{ }$ & $\sqrt{ }$ & \\
\hline Epiacuta pennsylvanica & $\sqrt{ }$ & $\sqrt{ }$ & & $\sqrt{ }$ & $\sqrt{ }$ & $\sqrt{ }$ \\
\hline Epilachna varivestis & & & & & $\sqrt{ }$ & \\
\hline Empoasca sp. & & $\sqrt{ }$ & & & & \\
\hline Epilachna sp. & & & $\sqrt{ }$ & & & \\
\hline Forficula auricularia & & & & & $\sqrt{ }$ & $\sqrt{ }$ \\
\hline Formica sp. & $\sqrt{ }$ & $\sqrt{ }$ & $\sqrt{ }$ & $\sqrt{ }$ & $\sqrt{ }$ & $\sqrt{ }$ \\
\hline Gryllus assimilis & $\sqrt{ }$ & $\sqrt{ }$ & $\sqrt{ }$ & $\sqrt{ }$ & $\sqrt{ }$ & $\sqrt{ }$ \\
\hline
\end{tabular}


Table 1. Contd.

\begin{tabular}{|c|c|c|c|c|c|c|}
\hline \multicolumn{4}{|l|}{ Geocoris sp. } & & \multicolumn{2}{|l|}{$\sqrt{ }$} \\
\hline Gnaphosa sp. & & & & $\sqrt{ }$ & & \\
\hline Graphocephala sp. & & $\sqrt{ }$ & & & $\sqrt{ }$ & \\
\hline Geophilus sp. & & & & $\sqrt{ }$ & & \\
\hline Halyomorpha halys & & & $\sqrt{ }$ & & & $\sqrt{ }$ \\
\hline Hapithus sp. & $\sqrt{ }$ & & & & & $\sqrt{ }$ \\
\hline Hodotermes sp. & & $\sqrt{ }$ & & & & \\
\hline Leptoglossus phyllopus & & $\sqrt{ }$ & & & & \\
\hline Leptysma marginicollis & $\sqrt{ }$ & & & $\sqrt{ }$ & $\sqrt{ }$ & \\
\hline Loxandrus sp. & $\sqrt{ }$ & & & $\sqrt{ }$ & $\sqrt{ }$ & \\
\hline Loxosceles reclusa & $\sqrt{ }$ & $\sqrt{ }$ & $\sqrt{ }$ & $\sqrt{ }$ & $\sqrt{ }$ & $\sqrt{ }$ \\
\hline Lygus lineolaris & & $\sqrt{ }$ & & & & \\
\hline Musca domestica & & & & & $\sqrt{ }$ & \\
\hline Macrodascillus sp. & & $\sqrt{ }$ & & & & \\
\hline Meconema thalassinum & & $\sqrt{ }$ & & & & \\
\hline Megaselia scalaris & $\sqrt{ }$ & & & & & \\
\hline Melanophthalma sp. & & $\sqrt{ }$ & & & & \\
\hline Monomorium mini & $\sqrt{ }$ & $\sqrt{ }$ & & $\sqrt{ }$ & $\sqrt{ }$ & $\sqrt{ }$ \\
\hline Myzinum maculate & & & & & $\sqrt{ }$ & \\
\hline Nabis roseipennis & $\sqrt{ }$ & $\sqrt{ }$ & & & $\sqrt{ }$ & \\
\hline Nebria brevicollis & & & & & $\sqrt{ }$ & \\
\hline Necrophila americana & & & & $\sqrt{ }$ & & \\
\hline Neoconocephalus sp. & & & & & $\sqrt{ }$ & \\
\hline Neotridactylus archboldi & $\sqrt{ }$ & $\sqrt{ }$ & & & & \\
\hline Oniscus asellus & & $\sqrt{ }$ & & & & \\
\hline Omphalapion hookerorum & $\sqrt{ }$ & & & & & $\sqrt{ }$ \\
\hline Oncometopia nigricans & & & & & & $\sqrt{ }$ \\
\hline Ocypus sp. & $\sqrt{ }$ & $\sqrt{ }$ & $\sqrt{ }$ & $\sqrt{ }$ & $\sqrt{ }$ & $\sqrt{ }$ \\
\hline Occopyylla sp. & & $\sqrt{ }$ & & & & \\
\hline Oncometopia sp. & & & $\sqrt{ }$ & & & \\
\hline Otiorhynchus sp. & $\sqrt{ }$ & $\sqrt{ }$ & & & $\sqrt{ }$ & $\sqrt{ }$ \\
\hline Oniscus sp. & & & & & & $\sqrt{ }$ \\
\hline Periplaneta americana & & $\sqrt{ }$ & & & & \\
\hline Petrognatha gigas & & & & & $\sqrt{ }$ & \\
\hline Paederus littoralis & & & & $\sqrt{ }$ & & \\
\hline Paederus olens & & & & $\sqrt{ }$ & & \\
\hline Paltothyreus tarsatus & $\sqrt{ }$ & $\sqrt{ }$ & & $\sqrt{ }$ & $\sqrt{ }$ & \\
\hline Paratettix sp. & & & & & $\sqrt{ }$ & \\
\hline Passalus sp. & $\sqrt{ }$ & $\sqrt{ }$ & & $\sqrt{ }$ & $\sqrt{ }$ & $\sqrt{ }$ \\
\hline Peritropis saldaeformis & & & & & $\sqrt{ }$ & \\
\hline Phalangium opilio & & & & & $\sqrt{ }$ & \\
\hline Pholcus phalagioides & & & & $\sqrt{ }$ & & \\
\hline Podagrica uniforma & & $\sqrt{ }$ & & & & \\
\hline Podagrica dilecta & & & & & & $\sqrt{ }$ \\
\hline Podura sp. & $\sqrt{ }$ & & $\sqrt{ }$ & $\sqrt{ }$ & $\sqrt{ }$ & $\sqrt{ }$ \\
\hline Pogonomyrmex sp. & $\sqrt{ }$ & $\sqrt{ }$ & $\sqrt{ }$ & $\sqrt{ }$ & & $\sqrt{ }$ \\
\hline Polydesmus sp. & $\sqrt{ }$ & & & $\sqrt{ }$ & $\sqrt{ }$ & \\
\hline Porcellio scaber & & $\sqrt{ }$ & & & & \\
\hline Pseudocistela pingius & & $\sqrt{ }$ & & & & \\
\hline Pyrrhocoris sp. & & & & & $\sqrt{ }$ & \\
\hline Rhynchomitra microrhina & & & & & & $\sqrt{ }$ \\
\hline Romalea guttata & $\sqrt{ }$ & $\sqrt{ }$ & $\sqrt{ }$ & $\sqrt{ }$ & $\sqrt{ }$ & \\
\hline
\end{tabular}


Table 1. Contd.

\begin{tabular}{|c|c|c|c|c|c|c|}
\hline Ruspolia sp. & & $\sqrt{ }$ & & & & $\sqrt{ }$ \\
\hline Scarites sp. & $\sqrt{ }$ & $\sqrt{ }$ & & $\sqrt{ }$ & $\sqrt{ }$ & $\sqrt{ }$ \\
\hline Scolytus sp. & $\sqrt{ }$ & & & & & \\
\hline Simulium sp. & $\sqrt{ }$ & & & & & \\
\hline Solenopsis mandibularis & $\sqrt{ }$ & & & $\sqrt{ }$ & $\sqrt{ }$ & \\
\hline Sphodromantis viridis & $\sqrt{ }$ & $\sqrt{ }$ & & & & \\
\hline Stomoxys calcitrans & & & & $\sqrt{ }$ & & \\
\hline Supella longipalpa & & $\sqrt{ }$ & & & & \\
\hline Tachina sp. & & & & & $\sqrt{ }$ & \\
\hline Tenebrio molitor & $\sqrt{ }$ & $\sqrt{ }$ & & $\sqrt{ }$ & $\sqrt{ }$ & \\
\hline Tetrix aresona & $\sqrt{ }$ & $\sqrt{ }$ & $\sqrt{ }$ & $\sqrt{ }$ & $\sqrt{ }$ & $\sqrt{ }$ \\
\hline Thrips sp. & $\sqrt{ }$ & & $\sqrt{ }$ & & & \\
\hline Thrombidium sp. & $\sqrt{ }$ & $\sqrt{ }$ & & $\sqrt{ }$ & $\sqrt{ }$ & \\
\hline Tipula sp. & $\sqrt{ }$ & & & & & \\
\hline Trachelas sp. & $\sqrt{ }$ & $\sqrt{ }$ & & $\sqrt{ }$ & $\sqrt{ }$ & \\
\hline Xyleborus sp. & $\sqrt{ }$ & & $\sqrt{ }$ & & & \\
\hline Xysticus sp. & $\sqrt{ }$ & & & & & $\sqrt{ }$ \\
\hline Zelanion sp. & & $\sqrt{ }$ & $\sqrt{ }$ & & $\sqrt{ }$ & \\
\hline Zelotes duplex & & & & & $\sqrt{ }$ & \\
\hline
\end{tabular}

$\sqrt{ }$ Macroarthropod species present.

Table 2. Macroarthropods abundance and species richness in relation to types of vegetable plots.

\begin{tabular}{lcc}
\hline Vegetable plot & No. of arthropods caught & No. of Species identified \\
\hline Tomato & 873 & 30 \\
Cabbage & 709 & 30 \\
Potato & 601 & 49 \\
Carrot & 480 & 48 \\
Maize & 399 & 54 \\
Lettuce & 284 & 21 \\
$\chi^{2}$ & 413 & 23.052 \\
df & 5 & 5 \\
P value & $0.00001^{*}$ & $0.00033^{*}$ \\
\hline
\end{tabular}

*Significant.

The high abundance of phytophagus group encountered in this study may possibly be due to the numerous herbivorous insect species in the world (Myburgh and Bredenkamp, 2000). They stated that there are over 400,000 herbivorous insect species feeding on about 300,000 vascular plants around the world. It could also be that these vegetables provide some necessary nutritional requirements of life for this group to thrive and multiply. Carrots are very rich in beta-carotene, cabbage contains high concentration of water, vitamin $\mathrm{k}$ and dietary fibre, and tomatoes are globally known sources of vitamins and minerals while fresh maize and potatoes are rich in dietary fibre (Tindall, 1986). The low population of the natural enemies of these arthropods may also be responsible for their high number since most vegetables cannot be cultivated without the use of synthetic pesticides which tend to destroy the non-target species especially the natural enemies (Myburgh and Bredenkamp, 2000).

The high variation between pitfall and hand picking techniques in favour of pitfall may probably be connected with the time the traps were left to stand. This is in agreement with Topping and Sunderland (1992), Duelli et al. (1999), Ward et al. (2001), Perner and Schueler (2004) and Ombugadu et al. (2017) who demonstrated that catches by pitfall traps may be influenced by timing and placement of the traps. It may also be that because the trap works throughout the time it stands, the number of catches may exceed that of the handpicking or it may possibly be that some of the soil macroarthropods are more active at night when it is difficult for them to detect the traps. On the contrary, study by Mwansat et al. (2012) recorded no variation between macroarthropods collected 


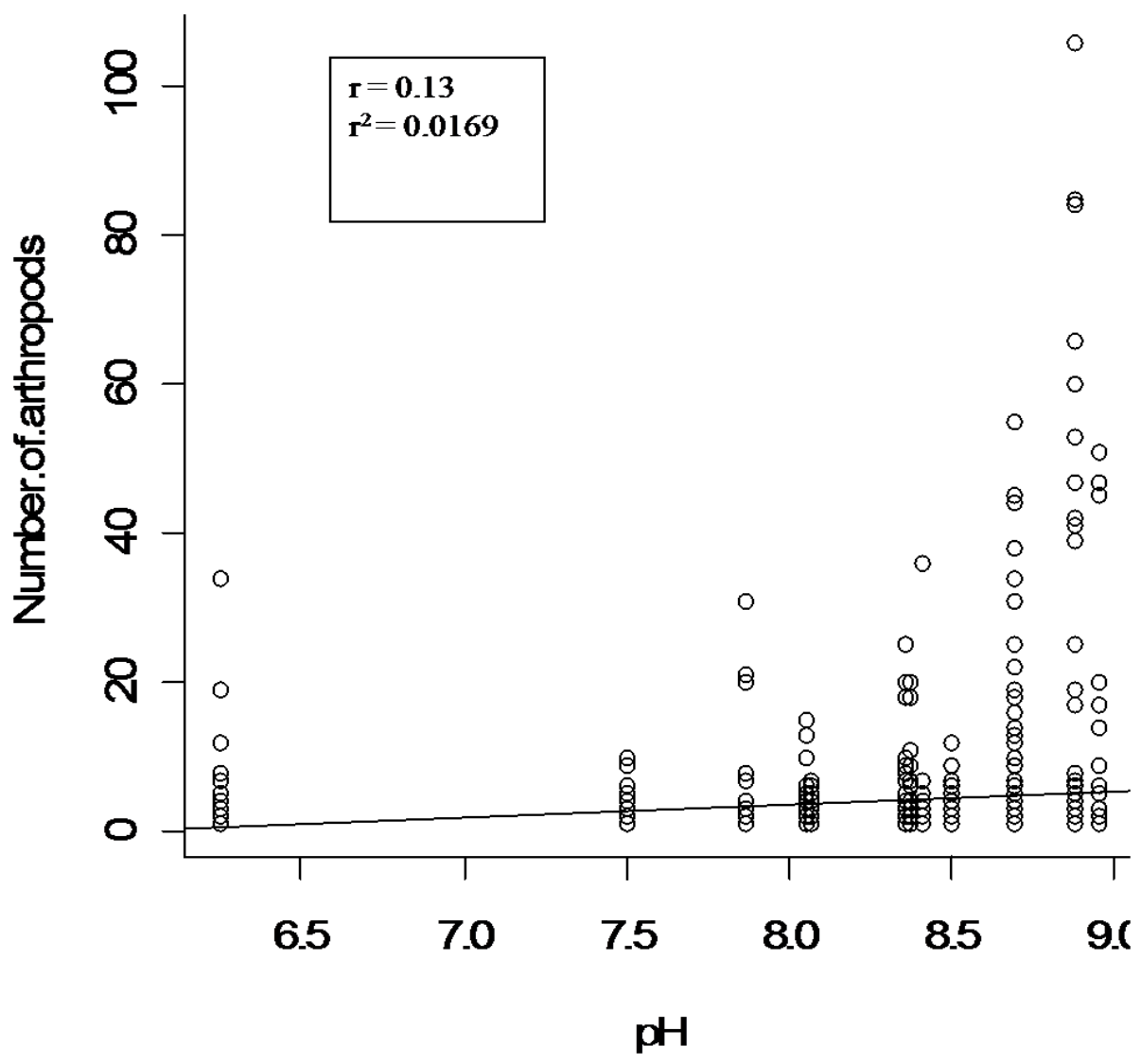

Figure 3. The association between the number of arthropods collected and $\mathrm{pH}$.

Table 3. Average soil temperature and $\mathrm{pH}$ values in relation to vegetable plots in Jos North LGA, Plateau State.

\begin{tabular}{lcc}
\hline Plot & Average Temperature $\left({ }^{\circ} \mathbf{C}\right)$ & Average $\mathbf{~ p H}$ \\
\hline Cabbage & 26.60 & 8.69 \\
Carrot & 28.00 & 7.87 \\
Lettuce & 26.60 & 8.95 \\
Maize & 26.30 & 8.37 \\
Potato & 25.70 & 8.36 \\
Tomato & 26.60 & 8.88 \\
\hline
\end{tabular}

by pitfall trap and hand capture techniques.

The high number of arthropods (mostly) insect recorded in tomato and cabbage plots in this study may probably be due to the indiscriminate use of insecticides by the farmers. Oral interview granted to the farmers during the preliminary study revealed that tomato and cabbage receive a minimum of 6 to 8 (insecticidal) sprays before harvest. This indiscriminate use of insecticides may lead to the destruction of the natural enemies of the pest species; thereby strengthening their resistance and subsequently insect resurgence. This is consistent with the work of Hardin et al. (1995), who reported that one of the causes of insect resurgence is their resistance to insecticides. In a recent review by Mafuyai (2014), insect resurgence is currently affecting agriculture and public health systems negatively. Mwansat (2014) also reported that the use of broad-spectrum insecticides to control insect pests usually leads to insect resurgence as these insecticides tend to reduce natural enemies' population while the target insect pests survives' and consequently resurge.

Maize plots were the most species rich in macroarthropods possibly due to lack or very low levels of pesticides sprays in the farms, thereby creating room for successful breeding of various arthropod species. This is in accordance with the findings of Price (1981) plus Cook 


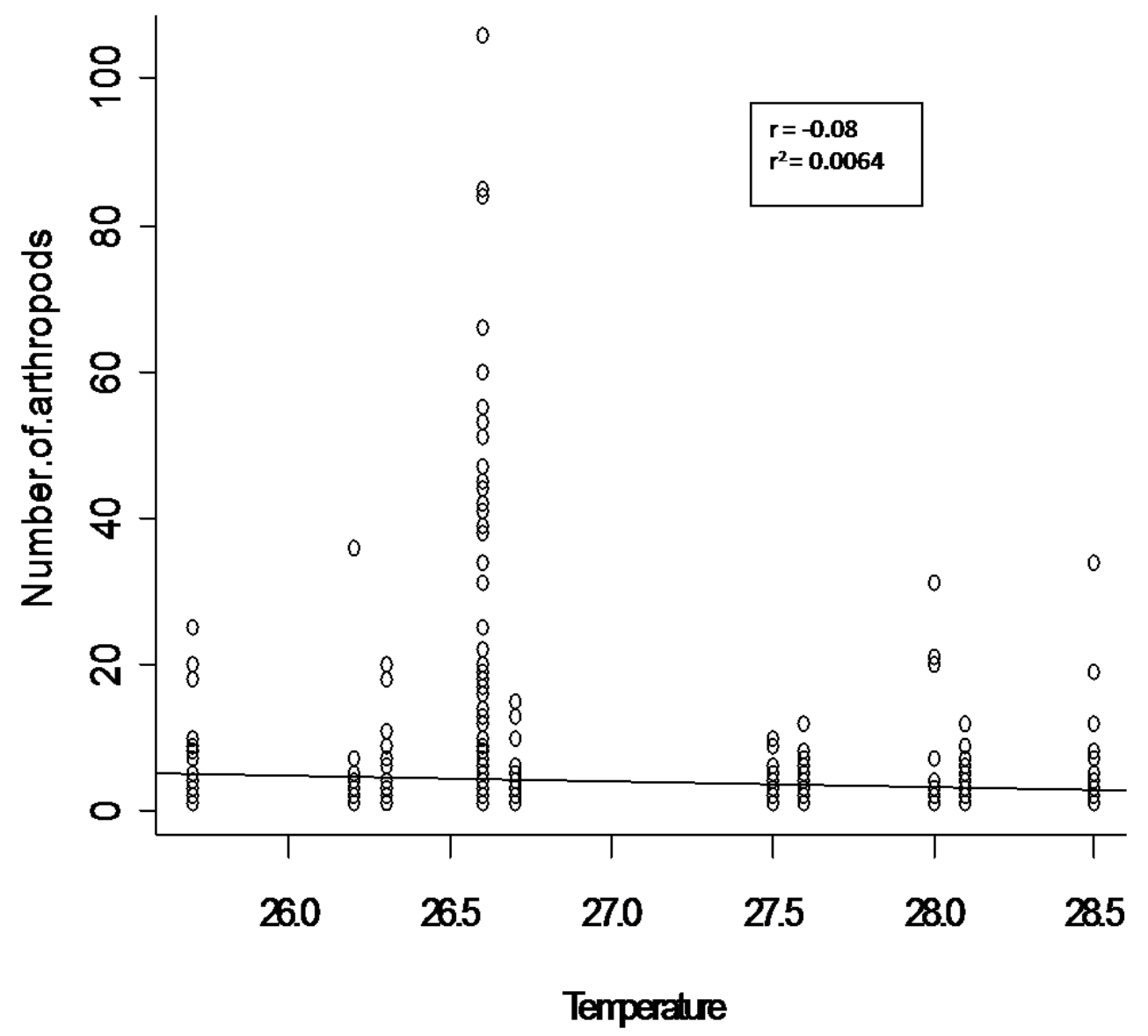

Figure 4. The association between the number of arthropods collected and temperature.

and Baker (1983) who reported that unsprayed corn fields host an army of beneficial arthropods which are valuable free source of natural pest control that should be nurtured, but could be easily and often carelessly destroyed by harsh pesticide regimens. Also, Mwansat et al. (2012) had the highest macroarthropods abundance in maize plots compared to other vegetable plots.

Macroarthropods abundance was influenced by the level of soil $\mathrm{pH}$ recorded in this study. The alkaline nature and possibly rich plant nutrients supported the growth of these vegetables and subsequently the breeding success of associated macroarthropods. This result is in agreement with that of Cancela Da Fonseca (1995) who reported positive correlations between soil $\mathrm{pH}$ and soil arthropod abundance. Also, this is similar to Enami et al. (1991) whose work showed a positive correlation between $\mathrm{pH}$ value and macroarthropod abundance. However, work by Swift and Woomer (1993) reported that low pH suggests acidity and consequently poor nutrient and hence low macroarthropods populations. Furthermore, Shakir and Ahmed (2014) showed that soil arthropod abundance had a weak negative correlation with soil $\mathrm{pH}$. Similar observation was reported by Klausman (2006) who found negative correlations between soil $\mathrm{pH}$ and total litter microarthropods. The level to which $\mathrm{pH}$ influenced the number of arthropods is $1.69 \%$ (coefficient of determination, $r^{2}=0.0169$ ), while the remaining percentage is accounted for by other factors such as geographical regions, environmental predators etc.

Soil temperature did not influence the abundance of macroathropods in vegetable plots possibly due to effects of global warming as one of the resultant effects of average increase in temperature is increase in ectoterm population for places with high latitude and decrease in population for those in the tropics. This is consistent with the work of Deutsch et al. (2008) who reported that there is a negative relationship between temperature and ectoterms in the tropics. This also agrees with the works by Porter et al. (1991), Crozier and Dwyer (2006) and Estay et al. (2009) that predicted general positive global warming effect on population density of ectoterms at high latitudes. This is contradictory with the findings of Wallwork (1970), Asikidis and Stamou (1991), Sulkava and Huhta (2003) and Mwansat et al. (2012) who recorded that temperature was strongly correlated with the abundance of arthropods, but extreme temperatures in colder climes had negative effects upon soil arthropods (Shakir and Ahmed, 2014). The level to which temperature influenced the abundance 
of arthropods was $0.64 \%$ (coefficient of determination, $r^{2}=$ 0.0064 ) in this study, while other factors are responsible for the remaining percentages.

\section{Conclusion}

The abundance of insects in soil often serves as indicators of good and healthy agricultural soil. Pitfall trapping is more efficient than hand-picking sampling technique for soil macroarthropods. The level of soil $\mathrm{pH}$ influences macroarthropods abundance whereas temperature does not. Farmers should be enlightened on the danger of continuous use of chemicals or synthetic fertilizers in their vegetable plots because these tend to acidify the soil which affects arthropods abundance.

\section{CONFLICT OF INTEREST}

The authors declare that they have no conflict of interest.

\section{REFERENCES}

Anthony, Y. (1977). A Laboratory manual of Entomology. University Press Ibadan. Pp. 59-88.

Asikidis, M., \& Stamou, G. (1991). Spatial and temporal patterns of an Oribatid mite community in an evergreen-sclerophyllous formation (Hortiatis, Greece). Pedobiologia, 35(1), 53-63.

Bater, J. E. (1996). Micro and Macro-arthropods. G. S. Hall (Ed.). Methods for the examination of Organismal Diversity in Soil Sediments. CAB International, Wallingford. 96p.

Borer, E. T., Seabloom, E. W., Tilman, D., \& Novotny, V. (2012). Plant diversity controls arthropod biomass and temporal stability. Ecology letters, 15, 1457-1464.

Borror, D. J., \& White, R. E. (1970). The Peterson Field Guide Series. A Field Guide to the Insects of America North of Mexico. Houghton Mifflin Company Boston. p. 404.

Cancela Da Fonseca, L. (1995). Characterization of benthic communities of St. Andrew's pond. Proceedings of the 4th Congress of the Alentejo. Pp. 36-51.

Castner, J. L. (2000). Photographic Atlas of Entomology and guide to Insect Identification, Feline Press Gainesville U.S.A. Inc. Pp. 74-223.

Cook, R. J., \& Baker, K. F. (1983). The nature and practice of biological control of plant pathogens. American Phytopathological Society.

Croft, B. A. (1990). Arthropod biological control agents and pesticides. New York: John Wiley and Sons.

Crozier, L., \& Dwyer, G. (2006). Combining population-dynamic and ecophysiological models to predict climate-induced insect range shifts. American Naturalists, 167, 853-866.

Darlong, V. T., \& Alfred, J. R. B. (1991). Effect of shifting cultivation on soil fauna with reference to earthworm in Northeast India. Advances in management and conservation of soil fauna. Veresh, G.K, Rajagopal, D., \& Viraktamath, C. A. (eds.), Oxford, IBH Publishing Co. Pvt. Ltd, New Delhi. Pp. 299-308.

Davidson, D. A., \& Grieve, I. C. (2006). The influence of soil fauna on soil structure attributes under limed and untreated, upland grassland. Land Degradation and Development, 17(4), 393.
Deutsch, C. A., Tewksbury, J. J., Huey, R. B., Sheldon, K. S., Ghalambor, C. K., Haak, D. C., \& Martin, P. R. (2008). Impacts of climate warming on terrestrial ectotherms across latitude. Proceedings of National Academic of Science U S A, 105(18), 6668-6672.

Devries, J. (1963). In Situ determination of physical properties of the surface Kyer of field soils. Proceedings of Soil Science Society of America, 33, 349-353.

Duelli, P., Obrist, M. K., \& Schmatz, D. R. (1999). Biodiversity Evaluation in Agricultural Landscape: Above-ground insects. Agriculture Ecosystem and Environment, 74, 33-64.

Edwards, C. A., \& Lofty J. R. (1969). The influences of agricultural practice on soil microarthropods population, in $\mathrm{J}$. G. Sheals (ed.). The soil Ecosystem. Synopsis publication and systematic Association London. Pp. 273-247.

Ellis, M. V. (2013). Impacts of pit size, drift fence material and fence configuration on capture rates of small reptiles and mammals in the new South Wales rangelands. Australian Zoologist, 36, 404-412.

Enami, Y, Shiraishi, H., \& Nakamura, Y. (1991). Use of soil animals as bioindicators of various kinds of soil management in Northern Japan, Japan. Agricultural Research Quarterly, 33, $117-128$

Estay, S. A., Lima, M., \& Labra, F. A. (2009). Predicting insect pest status underclimate change scenarios: combining experimental data and population dynamics modelling. Journal of Applied Entomology, 133, 491-499.

Hardin, M. R., Benrey, B., Colt, M., Lamp, W. O., \& Barbosa, P. (1995). Arthropod pest resurgence: an overview of potential mechanisms. Crop protection, 14(1), 1-18.

Henri, M. A., Xavier, D., \& Phillipe, L. (2002). Soil biodiversity: Myth, reality or coming? Oikos, 96(1), 3-24.

Hillel, D. (1980). Fundamentals of soil Physics. New York Academic. Pp. 412.

Hooper, D. U., Chapin lii, F. S., Ewel, J. J., Hector, A., \& Inchausti, P. (2005). Effects of biodiversity on ecosystem functioning: a consensus of current knowledge. Ecological Monographs, 75, 3-35.

Imam, T., Yusuf, A., \& Mukhtar, M. (2010). A survey of some insect pests of cultivated vegetables in three selected irrigation areas along Jakara river, Kano, Nigeria. International Journal of Biological and Chemical Sciences, 4(2), 400-406.

Johansson, M. B., Berg, B., \& Meentemeyer, V. (1995). Litter mass-loss rates in late stages of decomposition in a climatic transect of pine forests. Long-term decomposition in a Scots pine forest. IX. Canadian Journal of Botany, 73(10), 15091521.

Klausman, L. (2006). Decomposition and microarthropod abundance in litter and soil in a Southern Appalachian wetlands complex. Proceedings of the National Conference on Undergraduate Research (NCUR). The University of North Carolina at Asheville. 6-8 April, Pp. 300-307.

Mafuyai, H. B. (2014). Insect Resurgence: Implication for Agriculture, Health and sustainable Environment. Being a Key note address of the $45^{\text {th }}$ Annual Conference of the Entomological Society of Nigeria, University of Abuja, $8^{\text {th }}$ October. p. 16.

Manasseh, M. T. (2005). A comparative study on the diversity, Distribution and Abundance of Microarthropods fauna in Plateau. Unpublished M.sc. thesis, Department of Zoology University of Jos, Nigeria. p. 7.

Mwansat, G. S. (2014). Insect Resurgence: Implication for Agriculture, Health and sustainable Environment. Entomological Society of Nigeria Newsletter, p. 2. 
Mwansat, G. S., Njila, H. L., \& Levi, R. Y. (2012). A Study of Species Diversity and Distribution of Soil Macroarthropod Fauna in Irrigated Vegetable Plots in Jos South Local Government Area, Plateau State, Nigeria. International Journal of Applied Research and Technology, 1(4), 89-94.

Myburgh, J. A., \& Bredenkamp, G. J. (2000). Macro Channel Reparian Vegetation of the Olifants River System in the Savanna Biome, Mpumalanga. Koedoe, 47(2), 37-60.

Ombugadu, A., Mwansat, G. S., Chaskda, A. A., \& Njila, H. L. (2017). Comparative insect abundance and diversity in Amurum Forest Reserve and surrounding farmlands. Ethiopian Journal of Environmental Studies and Management, 10(49), 1200-1210.

Perner, J., \& Schueler, S. (2004). Estimating the density of ground-dwelling arthropods with pitfall traps using a nestedcross array. Journal of Animal Ecology, 73(3), 469-477.

Porter, J. H., Parry, M. L., \& Carter, T. R. (1991). The potential effects of climatic change on agricultural insect pests. Agriculture and Forest Meteorology, 57, 221-240.

Price, P. W. (1981). Relevance of Ecological Concepts in Practical Biological Control. Beltsville Symposia in Agricultural Research \#5 Biological Control in Crop Production.

Roth, C. H. (1985). Infiltrabilitat von Latossolo-Roxo-Boden in Nordparana, Brasilien, in Feldversuchen zur Erosionskontrolle mit verschiedenen Bodenbearbeitungs-systemen und Rotationen. Göttinger Bodenkundliche Berichte, 83, 1-104.

Santos, S. A. P., Eduardo Cabanas, J., \& Alberto Preira, J. (2007). Abundance and diversity of soil arthropods in olive grove ecosystem (Portugal): Effect of pitfall trap type. European Journal of Soil Biology, 43, 77-83.

Scherber, C., Eisenhauer, N., Weisser, W. W., Schmid, B. \& Voigt, W. (2010). Bottom-up effects of plant diversity on multitrophic interactions in a biodiversity experiment. Nature, 468, 553-556.

Seastedt, T. R., \& Crossley, D. A. (2004). The influence of Arthropods on Ecosystems. Bioscience, 34,157-161.

Sfenthourakis, S., Anastasiou, I., \& Strutenschi T. (2005). Altidunal terrestrial isopod diversity. European Journal of Soil Biology, 41, 91-98.

Shakir, M. M., \& Ahmed, S. (2015). Seasonal abundance of soil arthropods in relation to meteorological and edaphic factors in the agroecosystems of Faisalabad, Punjab, Pakistan. International journal of biometeorology, 59(5), 605616 .

Sharma, H. C. (2013). Climate Change Effects on Insects: Implication for Crop Production and Food Security. In: Combating Climate Change: An Agricultural Perspective. CRC Press, Pp. 213-236.

Shattuck, S. O. (2000). Australian Ants, their Biology and Identification. CSIRO Publishing. p. 226.

Skaife, S. H., Ledger, J., \& Bannister, A. (1979). African Insect. Strulk Publishers. p. 354
Sulkava, P., \& Huhta, V. (2003). Effects of hard frost and freezethaw cycles ondecomposer communities and mineralization in boreal forest soil. Appl. Soil Ecol., 22(3), 225-239.

Swift, M. J., \& Woomer, P. (1993). Organic matter and sustainability of agricultural systems: definition and measurement. In: Mutongoy, K. J., \& Merkx, R. (eds.) soil organic matter dynamics and sustainability of tropical as culture leuven: IITA/J. Willey, Pp. 3-18.

Thuo, N. (2016). Insect in the Life of a farmer. Available at https://wefarm.org/insects-in-the-life-of-a-farmer/. Accessed in April 2018.

Tindall, H. D. (1986). Vegetables in the Tropics. Macmillan Education Ltd. Houndmills, Basingstoke, Hampshire. 527p.

Topping, C. J., \& Sunderland, K. D. (1992). Limitations to the use of pitfall traps in Ecological studies exemplified by a study of spiders in a field winter wheat. Journal of Applied Ecology, 29, 485-491.

Tuf, I. H. (2015). Different collecting methods reveal different ecological groups of centipedes (Chilopoda). Zoologia, 32(5), $345-350$

University of Jos Meteorological Station (2012). The vegetation and edaphic features of Plateau State. Department of Geography and Planning, Faculty of Environmental Science.

Walker, M., \& Jones, T. H. (2003). Relative roles of top-down and bottom-up forces in terrestrial tritrophic plant-insect herbivore-natural enemy systems. Oikos, 93, 177-187.

Wallwork, J. A. (1976). The Distribution and Diversity of Soil Fauna. Academic Press London. Pp. 112-355.

Ward, D. F., New, T. R., \& Yen, A. L. (2001). Effects of pitfall trap spacing on the abundance, richness and composition of invertebrate catches. Journal of Insect Conservation, 5(1), 4753.

Zimmer, M., Brauckmann, H. J., Broll, G., \& Topp, W. (2000). Correspondence analytical evaluation of factors that influence soil macroarthropod distribution in abandoned grassland. Pedobiologia, 44, 695-704. 